bruck, ausgeftattet, wie benn bie $\mathfrak{A}$ hastattung bes ganzen $\mathfrak{B}$ uches - ęs wurbe bies bereits in ber \$ejprechung bes eriten 2 andes bervorgeboben

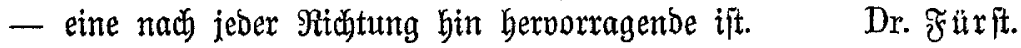

\title{
IV. Batutitzen.
}

\section{Erterminator,}

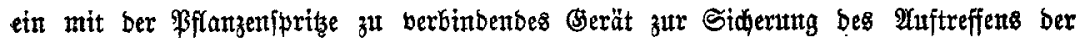
Flizffigtet auf bie zut bejprengenben Pflanzen.

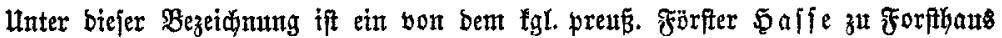

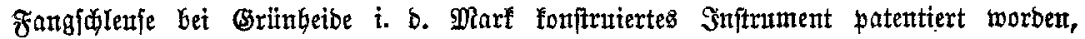
welches ein Sillfsmittel beim Befpriben ber juntgen Riefern zux Befämpfung ber Sdütte franfbeit feit foll.

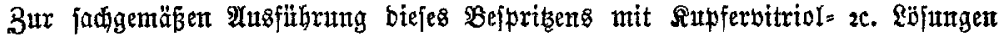

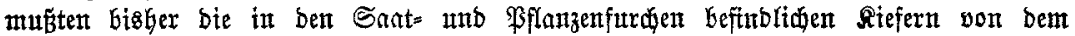

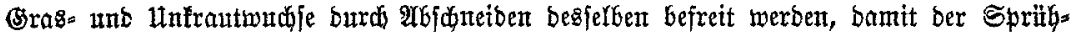

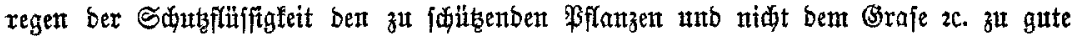
fam. Diejes Entfernen bes (5rajes $2 c$. erforbert viel Bett unb arbeit unb verurjadjt

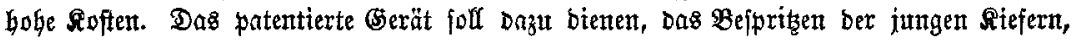

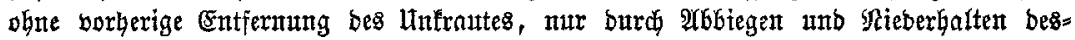
jelbert zu ermöglidłen.

Förifter $\mathfrak{S}$ afje bejuretbt biejes berät in folgender $\mathfrak{B}$ eife:

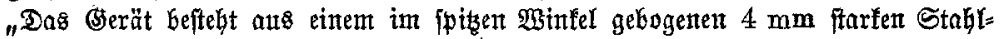

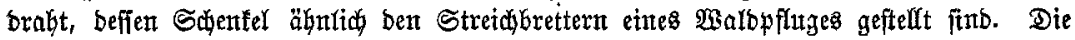

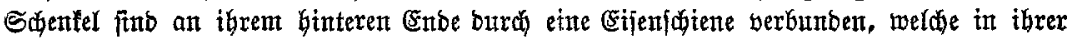
Mitte an einem ca. $25 \mathrm{~mm}$ Iangen, gebogenen Eifenftidfe bie $\mathfrak{I}$

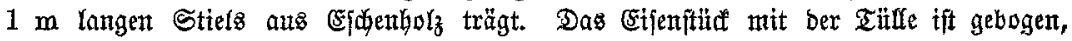

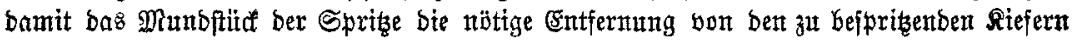

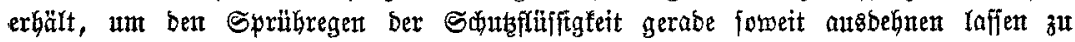

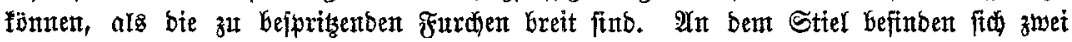

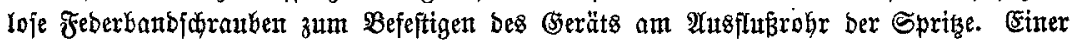

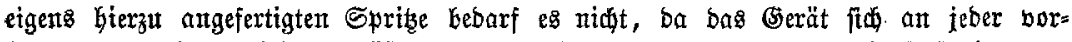

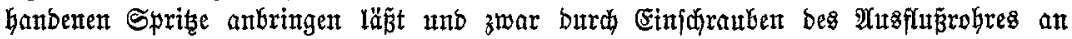

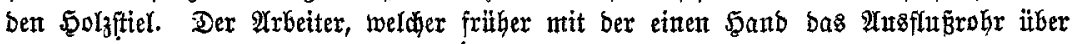

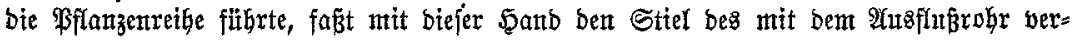
Gunbenten Seräts unto fübrt bas Dreied besfelbent mit ber Spitze in ber Mitte bie

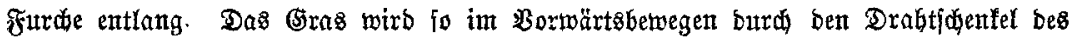

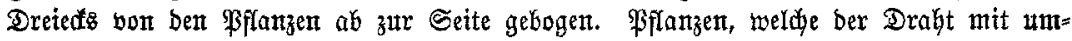
biegt, fanellen, Da fie um bie 3eit bes Spribens berholgt - ftetf - fint, in bas Dreied zurïa, wo ftet ber Sprübregen bintreffen muß̃."

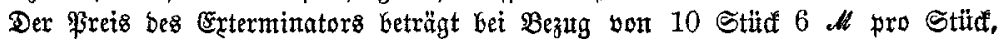
bei Bez̆ yon wentiger wie 10 Stüf $7,50 \mathrm{AH}$. 